\title{
Reaction of $\mathrm{Cr}$ Atoms with $\mathrm{O}_{2}$ at Low Pressures: Observation of New Chemiluminescence Bands from $\mathrm{CrO}_{2}{ }^{*}$
}

\author{
Hyung Su Son and Ja Kang Ku* \\ Deparment of Chemistry, Center for Integrated Molecular Systems, \\ Pohang Lniversity of Science and Technologv, Pohang 790-784, Korea \\ Received November 14, 2003
}

\begin{abstract}
Ground and low-ly ing electronic states of $\mathrm{Cr}$ atoms in the gas phase were generated from photoly sis of $\mathrm{Cr}(\mathrm{CO})_{6}$ vapor in $\mathrm{He}$ or Ar using an unfocussed weak $U V$ laser pulse and their reactions with $\mathrm{O}_{2}$ and $\mathrm{N}_{2} \mathrm{O}$ were studied. When 0.5-1.0 Torr of $\mathrm{Cr}(\mathrm{CO})_{6} / \mathrm{O}_{2} / \mathrm{He}$ or Ar mixtures were photolyzed using 295-300 $\mathrm{nm}$ laser pulses. broadband chemiluminescence peaked at $\sim 420$ and $\sim 500 \mathrm{~nm}$. respectively, was observed in addition to the atomic emissions from $z^{\circ} \mathrm{P}^{\circ} z^{5} \mathrm{P}^{\circ}$. and $\mathrm{y}^{\circ}$ states of $\mathrm{Cr}$ atoms. When $\mathrm{N}_{2} \mathrm{O}$ was used instead of $\mathrm{O}_{2}$. no chemiluminescence was observed. The chemiluminescence intensities as well as the LIF intensities for those three low-lying electronic states $\left(a^{7} S_{3}, a^{5} S_{2}\right.$ and $a^{5} D_{I}$ ) showed second-order dependence on the photolysis laser power. Also. the chemiluminescence intensities were first-order in $\mathrm{O}_{2}$ pressure, but the presence of excess Ar showed a strong inhibition effect on them. Based on the experimental results, the chemiluminecent species in this work is attributed to $\mathrm{CrO}_{2}^{*}$ generated from hot ground state $\mathrm{Cr}$ atoms with $\mathrm{O}_{2}$. The apparent radiative lifetimes of the chemiluminescent species and collisional quenching rate constants by $\mathrm{O}_{2}$ and Ar also were investigated
\end{abstract}

Key Words : $\mathrm{Cr}$ atoms. Chemiluminescence, $\mathrm{CrO}_{2}^{*}$

\section{Introduction}

Reactions of transition metal (TM) atoms in the gas phase with $\mathrm{O}_{2}$ and oxygen containing molecules have drawn substantial interest during the past two decades. and have been an area of continuing research. ${ }^{1-3}$ Many research groups have studied the influence of the ground and lowlying electronic states on the reactivity of $\mathrm{TM}$ atoms in oxidation reactions. $^{+12}$ It has been reported that $\mathrm{Sc}$, Ti and V atoms evaporated from a hot crucible react with $\mathrm{O}_{2}$ or other oxygen containing molecules to produce cheniluminescent TM oxides, and the vibrational structures of the chemilumunescence (CL) spectra have been analyzed. ${ }^{13-15}$ Ritter and Weisshaar have studied reactions of the ground state Sc. $\mathrm{Ti}$, and $\mathrm{V}$ atoms with $\mathrm{OX}\left(\mathrm{X}=\mathrm{N} . \mathrm{O} . \mathrm{N}_{2}\right)$ at $300 \mathrm{~K}$. They found that all the exothermic $\mathrm{O}$ atom transfer reactions were very inefficient. ${ }^{16}$

Parnis and co-workers generated the ground state $\mathrm{Cr}$ atoms by multiphoton dissociation of $\mathrm{Cr}(\mathrm{CO})_{6}$ at $559 \mathrm{~nm}$ and studied reactions of ground state $\mathrm{C}_{\mathrm{r}}$ atoms with $\mathrm{O}_{2}$ and other oxygen containing molecules under pseudo-first-order conditions at $298 \mathrm{~K}^{17}$ They observed relatively fast removal rate of the ground state $\mathrm{Cr}$ atoms which depended on the $\mathrm{O}_{2}$ pressure as well as on the total pressure. However. they did not observe CL as well as laser-induced fluorescence from $\mathrm{CrO}\left(\mathrm{X}^{5} \mathrm{P}\right)$.

In the previous report, we have shown that the ground state $\mathrm{FeO}$ molecules can be generated easily at room temperature by photolyzing $\mathrm{Fe}(\mathrm{CO})_{5}$ vapor in a $\mathrm{Fe}(\mathrm{CO})_{5} / \mathrm{O}_{2}$ or $\mathrm{N}_{2} \mathrm{O} / \mathrm{He}$ mixture using unfocussed weak UV laser pulses. and suggested that the highly unsaturated $\mathrm{Fe}(\mathrm{CO})_{x}$ fragments can react with $\mathrm{O}_{2}$ or $\mathrm{N}_{2} \mathrm{O}$ to generate ground state $\mathrm{FeO}$ molecules. ${ }^{\text {is }}$
We have applied the same method to look for the formation of the ground state $\mathrm{CrO}$ by photolyzing $\mathrm{Cr}(\mathrm{CO})_{6} / \mathrm{O}_{2}$ (or $\mathrm{N}_{2} \mathrm{O}$ )/He (or Ar) mixtures. Indeed. we have identified the formation of the ground state $\mathrm{CrO}$ from the reaction of highly unsaturated $\mathrm{Cr}(\mathrm{CO})_{x}$ fragments with $\mathrm{O}_{2}$ and $\mathrm{N}_{2} \mathrm{O}$ by observing laser-induced fluorescence (LIF) signal from $\mathrm{CrO}\left(\mathrm{B}^{5} \Pi_{\Omega}\right) \leftarrow \mathrm{CrO}\left(\mathrm{X}^{5} \Pi_{\Omega}\right)$ transition and reported depletion kinetics of the ground state $\mathrm{CrO}^{19}$ During the kinetic study of the ground state $\mathrm{CrO}$. we discovered a very broad structureless $\mathrm{CL}$ spectrum when the low pressure $\mathrm{Cr}(\mathrm{CO})_{6} /$ $\mathrm{O}_{2} / \mathrm{He}$ or Ar mixtures were photolyzed.

In the present work, we report studies on the CL signal observed from photolyzing $\mathrm{Cr}(\mathrm{CO})_{6}$ vapors in the $\mathrm{Cr}(\mathrm{CO})_{6} /$ $\mathrm{O}_{2} / \mathrm{He}$ or Ar gas mixtures. The dependence of CL intensities on the photolysis laser power, $\mathrm{O}_{2}$ and $\mathrm{Ar}$ pressures, and optical pumping results strongly support that the emitting species is $\mathrm{CrO}_{2}^{*}$ generated from the hot ground state $\mathrm{Cr}$ atoms with $\mathrm{O}_{2}$.

\section{Experimental Method}

An experimental setup used for this work is basically the same as that reported previously. ${ }^{18}$ The reaction cell was made of a $1 \mathrm{~L}$ Pyrex bulb and two-pairs of $2.5 \mathrm{~cm}$ Pyrex $\mathrm{O}-$ ring joints were attached to the bulb for the laser bean path and for the comection to a gas handling vacuum rack. A premixture of $10 \% \mathrm{O}_{2}$ in $\mathrm{He}$ or in Ar was slowly flowed through over $\mathrm{Cr}(\mathrm{CO})_{6}$ powder at $273 \mathrm{~K}$ to entrap the $\mathrm{Cr}(\mathrm{CO})_{6}$ vapor, and the resulting gas mixture was introduced to the photolysis/LIF cell. A typical flow rate of the gas mixture in the reaction cell was $0.2 \mathrm{mmol} \mathrm{min}^{-1}$. The actual $\mathrm{Cr}(\mathrm{CO})_{6}$ vapor pressure in the flowing cell was estimated to 
be about $2.5 \mathrm{mT}$ Torr under our experimental conditions by comparing the IIF intensities of the ground state Cr atoms with those from premixtures of known compositions. The total pressure in the cell was controlled by adjusting the openings of an inlet needle valve and an exit Teflon valve. When the pressure in the cell was stabilized, unfocussed UV laser pulses in the 290-300 $\mathrm{nm}$ regions were directed to the cell. The pulse energy of the photolysis laser (Quantel YG681-TDL .50 with NBP, $8 \mathrm{~ns}$ ) was $0.7-1.0 \mathrm{~mJ} / \mathrm{pulse}$ and the beam diameter was $7 \mathrm{~mm}$. However, the pulse energies of the photolysis laser were varied from $0.30 \mathrm{~m} J$ to $1.60 \mathrm{~mJ}$ to investigate the power dependence of $\mathrm{CL}$. and the atomic emission signals.

A photolysis and probe method was employed for I.IF experiments. The pulse energy and line width of the probe laser (Quantel YG581-TDI.60 with NBP and DGO) were $0.1-0.2 \mathrm{~m} .1 /$ pulse and $\sim 0.1 \mathrm{~cm}^{-1}$, respectively, at the frequency doubled wavelength.

The $\mathrm{Cl}$. signal and the I,IF intensities were monitored at the right angle with respect to the laser beam direction by using a $50 \mathrm{~cm}$ monochromator (Spex $1870 \mathrm{C}$ ) ecjuipped with a holographic grating and a Hammamatsu R928 photomultiplier (PM) tube. The signal from the PM tube was digitized with a transient digitizer (Tektronix 7912HB) and transferred to a laboratory computer for signal averagsing and storage.

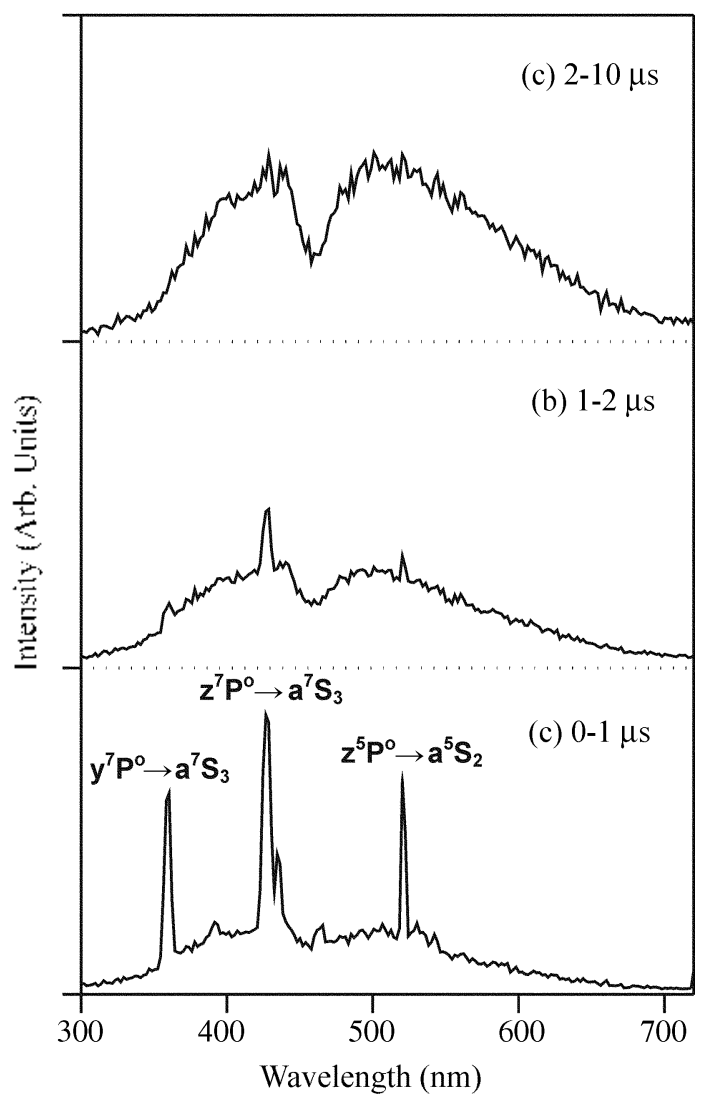

Figure 1. Tima-resolved CL spectra observed from photolysis of a $\mathrm{Cr}(\mathrm{CO})_{/} / \mathrm{O}_{2} / \mathrm{He}$ mixture using unfocussed IV laser pulses; (a) $0-1 \mu$ s. (b) $1-2 \mu \mathrm{s}$ and (c) 2-10 $\mu \mathrm{s}$. Ihe $\mathrm{Cr}\left(\mathrm{CO}_{6}\right.$ vapor was entrapped by flowing a premixture of $10 \% \mathrm{O}_{2}$ in I $\mathrm{l}$ and total pressure was 0.5 lorr.

\section{Results}

A. Chemiluminescence spectrum. When $0.5-1.0$ Torr of $\mathrm{Cr}(\mathrm{CO})_{6} / \mathrm{O}_{2} / \mathrm{He}$ or Ar mixtures were photolyzed using unfocussed weak UV laser pulses in the $290-300 \mathrm{~nm}$ region. broad band $\mathrm{CL}$, was observed in the $350-700 \mathrm{~nm}$ region as plotted in Figure 1. The sharp features at 360,425 and 520 nm correspond to $\mathrm{Cr}$ atomic emission from $\mathrm{y}^{7} \mathrm{P}^{0}, 7^{7} \mathrm{P}^{\circ}$ and $z^{5} \mathrm{P}^{6}$ state, respectively. ${ }^{20.21}$ These three atomic emissions were always observed in addition to the dominant generation of the ground state $\mathrm{Cr}$ atoms under our experimental conditions supporting two distinctive photodissociation mechanism for $\mathrm{Cr}(\mathrm{CO})_{6}$ reported by Tyndall and Jackson. ${ }^{22}$ The atomic emissions disappeared within $2 \mu \mathrm{s}$, while the $\mathrm{Cl}$. was observed for longer than $10 \mu \mathrm{s}$. Note that the apparent long duration of the atomic emissions is due to the long sampling time of the transient digitizer to catch relatively weak Cl. signal appearing in late time, and real atomic emissions disappeared within $150 \mathrm{~ns}$ at shorter time resolution of the transient digitizer. When $\mathrm{N}_{2} \mathrm{O}$ was used instead of $\mathrm{O}_{2}$, or a $\mathrm{Cr}(\mathrm{CO})_{6} / \mathrm{He}$ mixture was photolyzed without $\mathrm{O}_{2}$, only the three atomic emissions were detected, and no $\mathrm{Cl}$. signal was observed. The three atomic emission intensities showed third-order dependence upon the photolysis laser power.

The Cl. spectra in Figure 1 show structureless continuum emissions peaked at around 400 and $500 \mathrm{~nm}$, respectively. Tfforts to resolve any vibrational band structures by increasing spectral resolution of the monochromator were unsuccessfiul. Thus, the nature of the emitting species seems

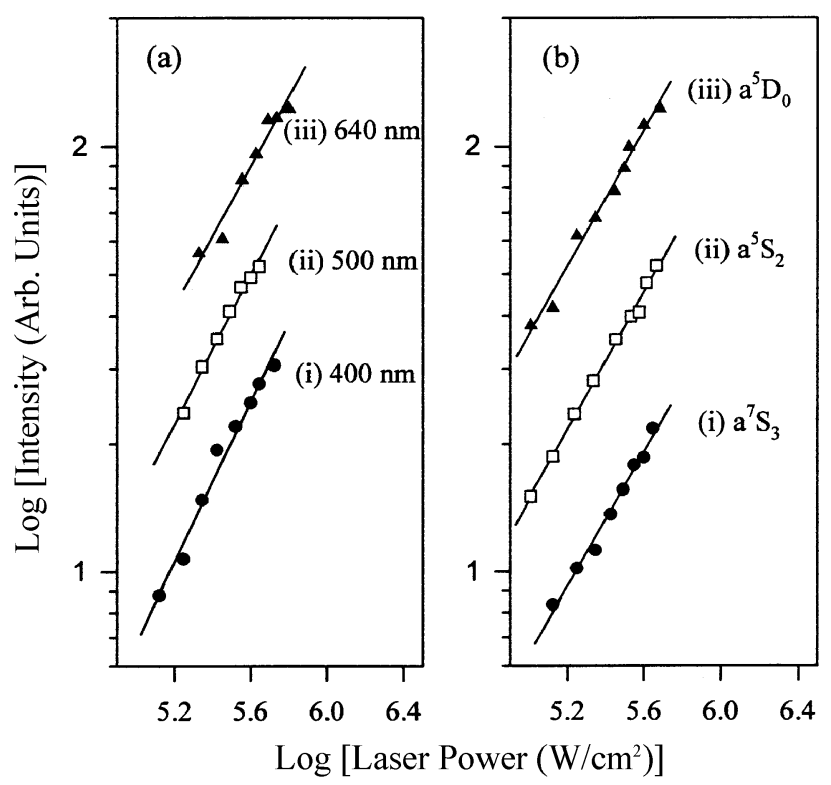

Figure 2. (a) Dependence of 'CL signal intensities on the photolysis laser power monitored at three dillerent wavelengths. The magnilude of the slopes is (i) $2.1 \div 0.2$. (ii) $2.0 \div 0.2$. and (iii) 1.9 \pm 0.2 . respectively. (b) Dependence of LIF intensities for the low-ly ing atomic statcs of Cr atoms on the photolysis laser power. The magnitude of the slopes is (i) $1.8 \pm 0.2$. (ii) $1.9=0.2$. and (iii) $1.9 \perp 0.2$, respectively. lo awoid congestion. plon (ii) and (iii) are vertically shifted. 
Table 1. Fxcitation and monitored wavelenglhs for photolysis laser ponter dependence

\begin{tabular}{|c|c|c|c|c|}
\hline & $\begin{array}{c}\lambda_{\text {pillisholvisis }} \\
(\mathrm{nm})\end{array}$ & $\begin{array}{c}\lambda_{\mathrm{exc}}(\mathrm{nm}) \\
\text { (Transition) }\end{array}$ & $\begin{array}{c}\lambda_{\text {als }}(\mathrm{nm}) \\
\text { (Transition) }\end{array}$ & $\begin{array}{c}\text { Prower } \\
\text { dependence }\end{array}$ \\
\hline Cl & $295.3^{4}$ & - & 400 & $2.1 \perp 0.2$ \\
\hline \multirow[t]{2}{*}{ Sigrial } & & & 500 & $2.0 \perp 0.2$ \\
\hline & & & & $1.9 \perp 0.2$ \\
\hline \multirow[t]{2}{*}{$\operatorname{Cr}\left(a^{7} S_{3}\right)$} & 295.3 & 373.2 & 520.8 & $1.8+0.2$ \\
\hline & & $\left.\left(x^{5}\right)^{\circ}\right)^{\circ} \leftarrow a$ & $\left(x^{5} \mathrm{P}_{3}{ }^{\circ} \rightarrow \mathrm{a}^{5} \mathrm{~S}_{2}\right)$ & \\
\hline \multirow[t]{2}{*}{$\mathrm{Cr}\left(\mathrm{a}^{5} \mathrm{~S}_{2}\right)$} & 295.3 & 387.0 & 392.1 & $1.9 \perp 0.2$ \\
\hline & & $\left.\left(x^{5} 1\right)_{1}^{0} \leftarrow a^{5} S_{2}\right)$ & $\left.\left(x^{5} \mathrm{I}_{1}^{\circ} \rightarrow \mathrm{a}^{5} \mathrm{l}\right)_{2}\right)$ & \\
\hline \multirow[t]{2}{*}{$\left.\operatorname{Cr}\left(a^{5} I\right)_{3}\right)$} & 295.3 & 389.4 & 392.1 & $1.9 \perp 0.2$ \\
\hline & & $\left(x^{5} \mathrm{I}_{1}^{\circ} \leftarrow \mathrm{a}^{5} \mathrm{D}_{0}\right)$ & $\left.\left(f^{5} \mathrm{I}_{1}^{\circ} \rightarrow \mathrm{a}^{5} \mathrm{l}\right)_{2}\right)$ & \\
\hline \multirow[t]{2}{*}{$\mathrm{Cr}\left(6^{5} \mathrm{I}_{+}{ }^{\circ}\right)$} & $295.7^{\wedge}$ & 295.7 & 391.9 & $2.9 \perp 0.1$ \\
\hline & & $\left(x^{5}\right)_{+}{ }^{0} \leftarrow a$ & $\left(f^{5} \mathrm{I}_{4}^{\circ} \rightarrow a^{5} \mathrm{I}_{4}\right)$ & \\
\hline \multirow[t]{2}{*}{$\mathrm{Cr}\left(\mathrm{y}^{\mathrm{T}} \mathrm{P}_{3}{ }^{\circ}\right)$} & $295.6^{\circ}$ & - & 359.3 & $2.7 \perp 0.2$ \\
\hline & & & $\left(y^{5} 3_{3}{ }^{\circ} \rightarrow a^{5} \mathrm{~S}_{3}\right)$ & \\
\hline $\left.\operatorname{Cr}\left(x^{7}\right]^{2} ;{ }^{\circ}\right)$ & 295.6 & - & $\begin{array}{c}427.5 \\
\left(/^{7} \mathrm{P}^{0}{ }^{0} \rightarrow \mathrm{a}^{5} \mathrm{~S}_{3}\right)\end{array}$ & $2.8 \perp 0.2$ \\
\hline
\end{tabular}

Von-resonant wavelengths for atomic tratsition. "Resonant wavelength for the $z^{5}\left[D_{+}{ }^{\circ} \leftarrow \mathrm{a}^{\top} \mathrm{S}\right.$ : atomic transition

to be a polyatomic molecule.

B. Dependence of CL and LIF intensities on the photolysis laser power. To investigate precursors for the emitting species in the reaction cell, the $\mathrm{Cl}$. intensities vs. photolysis laser power were monitored at three different wavelengths. The Cl. signal intensities monitored at 400,500 and $640 \mathrm{~nm}$, respectively, showed second-order dependence on the photolysis laser power as plotted in Figure 2(a). We have also investigated the photolysis laser power dependence of the I.IF intensities for the low-lying energy states of $\mathrm{Cr}$ atoms produced in the reaction cell. The excitation and fluorescence wavelengths for the $a^{7} S_{3}, a^{5} S_{2}$ and $a^{5} D_{3}$ states are shown in Table 1. As depicted in Figure 2(b). the I.IГ intensities from the a ${ }^{7} S_{3}$, a ${ }^{5} S_{2}$ and $a^{5} D_{0}$ states also showed second-order dependence on the photolysis laser power: ]hus, the dependence of the CL intensities as well as the LIF intensities from low-lying $\mathrm{Cr}$ atomic states on the photolysis laser power strongly supports that one of the reactants for the emitting species must be $\mathrm{Cr}$ atoms generated in the lowlying electronic states.

C. Dependence of $\mathrm{CL}$ intensities upon $\mathrm{O}_{2}$ and $\mathrm{Ar}$ pressures. Premixed gases with $1,2,5$, and $10 \% \mathrm{O}_{2}$ in $\mathrm{Ar}$ were prepared to investigate $\mathrm{O}_{2}$ pressure dependence of the $\mathrm{CL}$ intensities. The premixed gases were used to entrap $\mathrm{Cr}(\mathrm{CO})$, vapor maintaining the same flow rate and the total pressure of the cell was kept the same at 0.5 Torr. The pulse energy of photolysis laser was $0.5 \mathrm{~mJ} /$ pulse. The $\mathrm{CL}$ intensities monitored at 400 and $500 \mathrm{~nm}$. respectively, showed first-oder dependence on $\mathrm{O}_{2}$ pressure when the $\mathrm{O}_{2}$ partial pressure was in the 5-50 milorr range as shown in Figure 3(a). Thus, the emitting species in this work must be formed by a direct reaction with $\mathrm{O}_{2}$.

The dependence of the CL intensities upon Ar buffer gas pressure also was studied under static conditions. For this
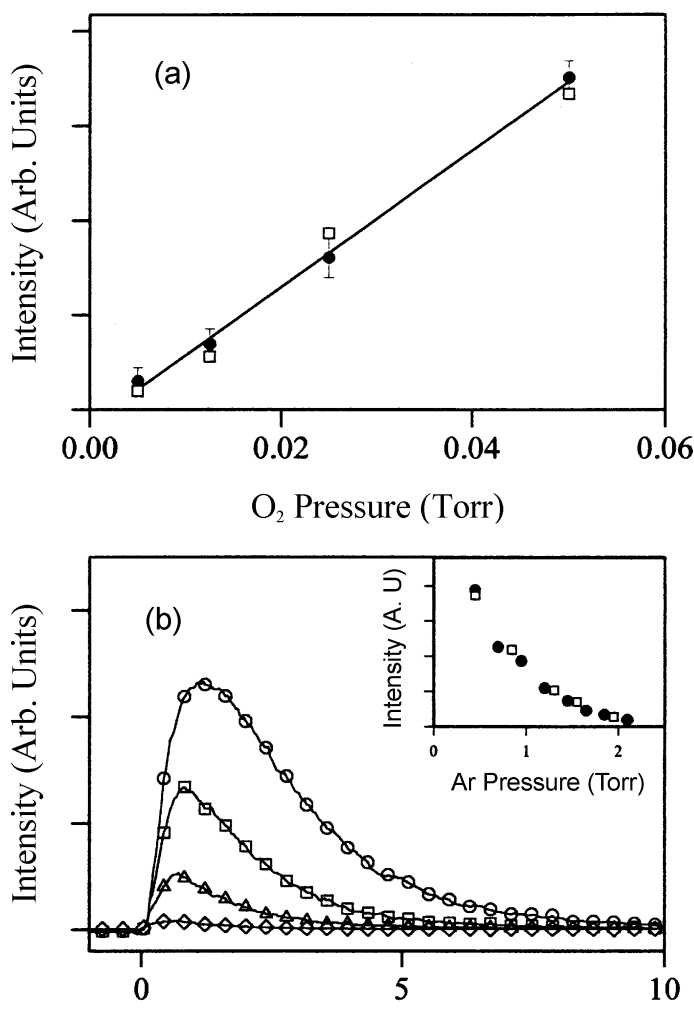

Time $(\mu s)$

Figure 3. (a) Oxygen pressure dependence of $\mathrm{CL}$ intensities monitored at 400 ( $)$ and 500 (Г.) nm. respectively. (b) Representative time probiles for the Cl. signal monitored at $400 \mathrm{~nm}$ vs. $A$ r bulter pressures: $0.45(\therefore) .0 .95(\lrcorner), 1.45(-)$ ) and 2.10 ( ) lorr of $\Lambda \mathrm{r}$. To awoid congestion. one data point from every 10 points is plotted. Time integrated CL intensities monitored at 400 (•) and 500 $(\ulcorner) \mathrm{Jm} w$. Ar pressure are shown in the insert of (b).

purpose, the premixed gas with $10 \% \mathrm{O}_{2}$ in $\mathrm{Ar}$ was used to entrap $\operatorname{Cr}(\mathrm{CO})_{6}$, vapor, and the cell pressure was adjusted to 0.5 Torr before adding extra $\mathrm{Ar}$ to the cell. Typical time profiles monitored at $400 \mathrm{~nm}$ for different Ar pressures are plotted in Figure 3(b). As shown in the insert, the time integrated $\mathrm{CL}$ intensity decreased exponentially as the $\mathrm{Ar}$ pressure increased. When the decaying part of the time profiles were analyzed, we obtained relatively small apparent quenching rate constants for the CL signal by Ar as shown in [able 2. These results strongly imply that presence of excess

Table 2. Apparent radiative lifetime and quenching rate constant of the $\mathrm{CrO}_{2} *$ by $\mathrm{O}_{3}$ and $\mathrm{Ar}^{2 \mathrm{~T}}$

\begin{tabular}{|c|c|c|c|c|c|}
\hline \multirow{2}{*}{$\begin{array}{l}\lambda_{\text {abss }} \\
\text { (1) }\end{array}$} & \multicolumn{3}{|c|}{ Pressure (Tom) } & \multirow{2}{*}{$\frac{k_{\mathrm{g}}}{\left(\mathrm{cm}^{3} \operatorname{molecule} \mathrm{I}^{\mathrm{l}}{ }^{\mathrm{l}}\right)}$} & \multirow{2}{*}{$\tau_{\text {rad }}(\mu s)^{h}$} \\
\hline & $\mathrm{O}_{2}$ & $\Delta \Gamma$ & $\mathrm{Cr}\left(\mathrm{CO}_{k}\right.$ & & \\
\hline \multirow[t]{2}{*}{400} & $0.05-0.65$ & 0.45 & 0.0025 & $8.0 \pm 0.5 \times 10^{-11}$ & $1.5 \pm 0.2$ \\
\hline & 0.05 & $0.45-1.05$ & 0.0025 & $6.2 \pm 0.5 \times 10^{-12}$ & $1.5 \pm 0.2$ \\
\hline \multirow[t]{2}{*}{500} & $0.05-0.65$ & 0.45 & 0.0025 & $9.0 \pm 0.5 \times 10^{-11}$ & $2.1 \pm 0.2$ \\
\hline & 0.05 & $0.45-1.05$ & 0.0025 & $6.3 \pm 0.3 \times 10^{-12}$ & $2.1 \pm 0.2$ \\
\hline $320^{\circ}$ & $>0.0016$ & & & & \\
\hline
\end{tabular}

"The composition of premixed gas was $10 \% \mathrm{O}$, in Ar. "Calculated from $1 / \tau=1 / \tau_{\mathrm{ral}}+\mathrm{k}_{4 \mid}^{\mathrm{Ar}}[\mathrm{Ar}]+\mathrm{k}_{41}{ }^{0}\left[\mathrm{O}_{2}\right]$. This hand emission was reported in Ref. 29. but wals not observed in this work 
Ar prevents the generation of the emitting species.

We also looked for the shapes of $\mathrm{Cl}$. time profiles at higher $\mathrm{O}_{2}$ pressures under static conditions. When $\mathrm{O}_{2}$ pressure was increased while keeping $\mathrm{Cr}(\mathrm{CO})_{0}$ and $\mathrm{Ar}$ pressure constant, both the rise and decay time of the $\mathrm{Cl}$. signal decreased. When the decay time $w$. $\mathrm{O}_{2}$ pressure was analyzed, the apparent quenching rate constants by $\mathrm{O}_{2}$ were $8.0 \pm 0.5 \times$ $10^{-11}$ and $9.0 \pm 0.5 \times 10^{-11} \mathrm{~cm}^{3}$ molecule ${ }^{-1} \mathrm{~s}^{-1}$ for the 400 and $500 \mathrm{~nm}$ emissions, respectively. Although the apparent quenching rate constants by $\mathrm{O}_{2}$ were much larger than those by $\mathrm{Ar}$, the time integrated $\mathrm{Cl}$. intensities in the presence of excess $\mathrm{O}_{2}$ did not decrease as sharply as those for Ar. Based on the measured quenching rate constants by $\mathrm{Ar}$ and $\mathrm{O}_{2}$, the apparent radiative lifetimes of the emitting species calculated from Stem-Volmer plots were $1.5 \pm 0.2$ and $2.1 \pm 0.2$ $\mu$ s for the 400 and $500 \mathrm{~nm}$ emissions, respectively. The very long apparent radiative lifetimes suggest that the emission might be originated from such a spin forbidden transition.

D. Depletion rate constants of $\operatorname{Cr}\left(a^{7} S_{3}\right), \operatorname{Cr}\left(a^{5} S_{2}\right)$, and $\operatorname{Cr}\left(\mathbf{a}^{5} \mathbf{D}_{\mathbf{0}}\right)$ atoms by $\mathbf{O}_{2}$. The variations of I.IF intensities from the low-lying states of $\mathrm{Cr}$ atoms were monitored $v s$.
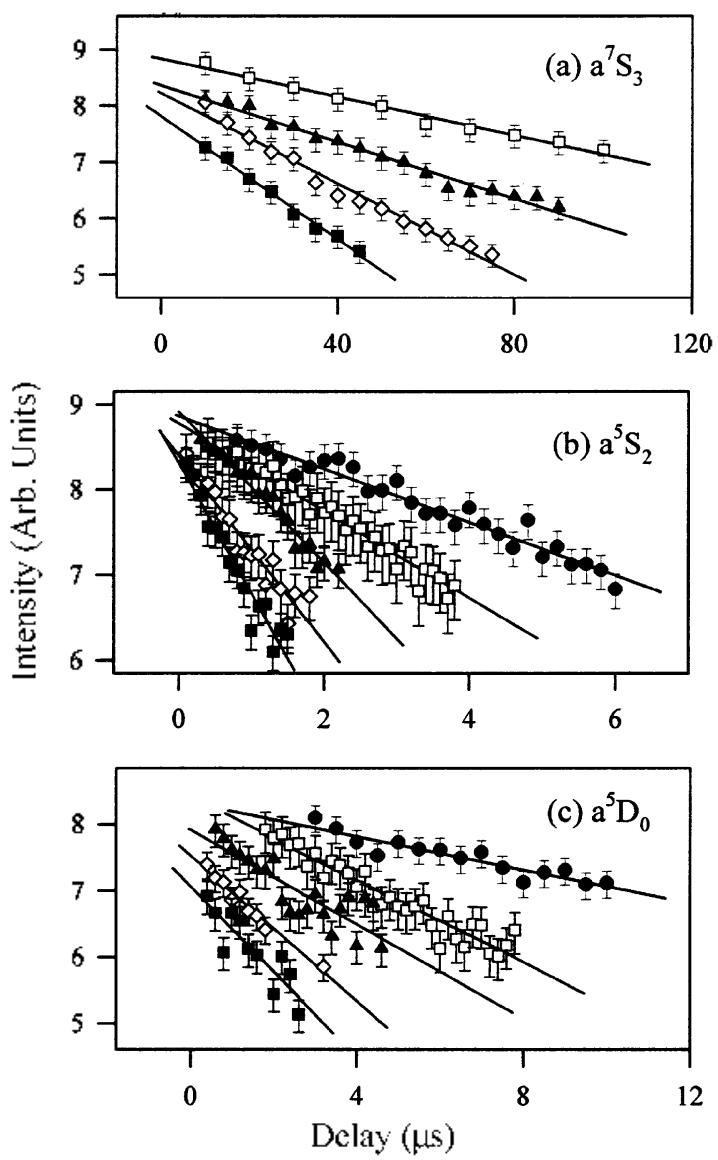

Figure 4. IDependence of I.If intensitjes of the low-lying alomic states of $\mathrm{Cr}$ atoms on the photolysis and probe delay time at different $\mathrm{O}_{2}$ pressures. The partial pressures of $\mathrm{Cr}\left(\mathrm{CO}_{6}\right.$ vapor and He were kept consiant at 0.45 Torr. The partial $\mathrm{O}_{2}$ pressures were

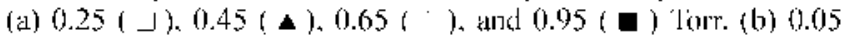

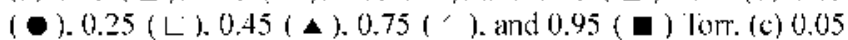
(๑). 0.25 (Г.). 0.45 (४). $0.75\left({ }^{\prime}\right)$ and 0.95 (ם) Torr. respectively.

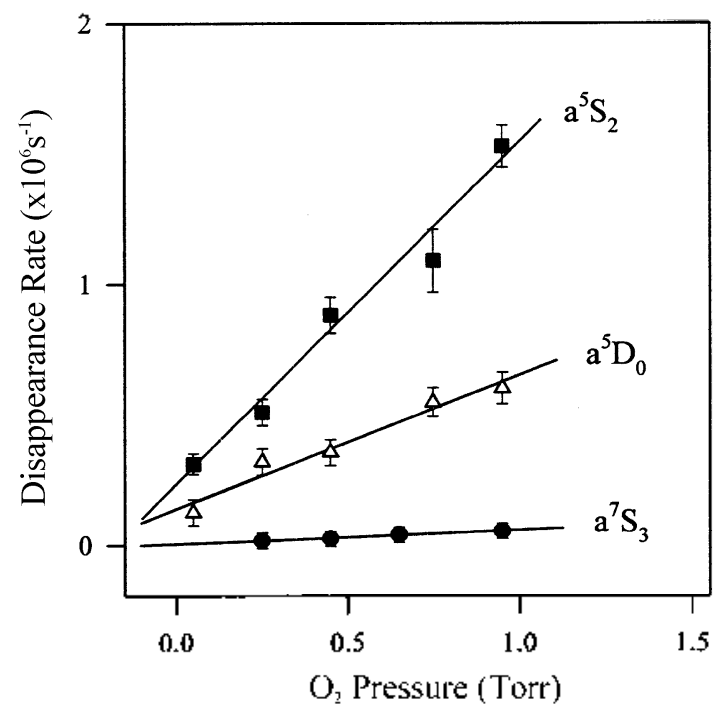

Figure 5. Oxyen pressure dependence of the distappearance rate for the low-ly ing atomic states of Cr atoms.

delay time between the photolysis and probe laser pulses at different oxygen pressures and plotted in Figure 4. The $\mathrm{Cr}(\mathrm{CO})_{6}$ vapor was entrapped using a $10 \% \mathrm{O}_{2}$ in $\mathrm{He}$ mixture. The pressure of the $\mathrm{Cr}(\mathrm{CO})_{0} / \mathrm{O}_{2} / \mathrm{He}$ mixture was kept constant at 0.5 Torr and additional $\mathrm{O}_{2}$ was added to the photolysis/l.IF cell. As shown in Figure 4, Cratoms in the ${ }^{5} S_{2}$ and $a^{5} D_{k}$ states were depleted much faster than the ground state $\left(a^{5} S_{3}\right)$. When the disappearance rates of the low-lying electronic states of $\mathrm{Cr}$ atoms $v s$. $\mathrm{O}_{2}$ pressure were replotted as in Figure 5, the bimolecular removal rate constants were obtained. As shown in Table 3, the bimolecular removal rate constant for the $\mathrm{Cr}_{\left(a^{5} \mathrm{~S}_{2}\right)}$ state by $\mathrm{O}_{2}$ is substantially larger than those for $\operatorname{Cr}\left(a^{7} S_{3}\right)$ and $\operatorname{Cr}\left(a^{5} D_{(1)}\right)$ even though the $\operatorname{Cr}\left(a^{5} D_{0}\right)$ state locates at $158 \mathrm{~cm}^{-1}$ above the $\operatorname{Cr}\left(a^{\mathrm{s}} \mathrm{S}_{2}\right)$ state.

E. Optical pumping of $\operatorname{Cr}\left(a^{5} D_{4}\right)$ and $C L$ intensities. The population of $\mathrm{Cr}$ atoms in the $\mathrm{a}^{5} \mathrm{D}_{4}$ state was increased intentionally by optical pumping to look for any change in the intensities of the CL signal. Since the Einstein A coefficient for $z^{5} D_{4}{ }^{11} \rightarrow a^{5} D_{4}$ transition is fairly large, ${ }^{21}$ and since the $z^{5} D_{4}{ }^{\circ}$ state can be generated directly by the photolysis laser pulse, the population in the $a^{5} \mathrm{D}_{4}$ state can be increased by photolyzing the gas mixture using $z^{5} \mathrm{D}_{4}{ }^{0} \leftarrow \mathrm{a}^{7} \mathrm{~S}_{3}$ atomic transition frequency. Figure $6($ a) shows the variation

Table 3. Removal rate constants for the low-lying electronic states of $\mathrm{Cr}$ by $\mathrm{O}_{2}$

\begin{tabular}{|c|c|c|c|}
\hline State & $\begin{array}{c}\lambda_{\text {wis }}(\mathrm{nm}) \\
\text { (Transition) }\end{array}$ & $\begin{array}{c}\dot{\lambda}_{\text {abs }}(\mathrm{nm}) \\
\text { (liansition) }\end{array}$ & $\begin{array}{c}\text { Rate constantst } \\
\left(\mathrm{cm}^{3} \text { molecule } s^{\prime}\right)\end{array}$ \\
\hline$a^{7} S_{3}$ & $\begin{array}{c}373.2 \\
\left(z^{5} P_{3}^{10} \leftarrow a^{7} S_{1}\right)\end{array}$ & $\begin{array}{c}520.8 \\
\left(z^{5} \mathrm{P}^{\prime \prime \prime} \rightarrow \mathrm{a}^{5} \mathrm{~S}_{2}\right)\end{array}$ & $1.7-0.3 \times 10^{-12}$ \\
\hline$a^{5} S_{2}$ & $\begin{array}{c}387.0 \\
\left(z^{5} D_{1}{ }^{\mathrm{c}} \leftarrow a^{5} \mathrm{~S}_{2}\right)\end{array}$ & $\begin{array}{c}392.1 \\
\left(z^{5} \mathrm{D}_{1}^{\prime \prime} \rightarrow \mathrm{a}^{5} \mathrm{D}_{2}\right)\end{array}$ & $4.0-0.6 \times 10^{-11}$ \\
\hline$a^{s}$ & $\begin{array}{c}389.4 \\
\left(z^{5} D_{1}^{\prime \prime} \leftarrow a^{s} D_{01}\right)\end{array}$ & $\begin{array}{c}392.1 \\
\left(z^{5} D_{1}^{\prime \prime} \rightarrow a^{5} D_{2}\right)\end{array}$ & $0.3 \times 10^{-11}$ \\
\hline
\end{tabular}

"Measured in the presence of 0.45 Tor I Ie. 


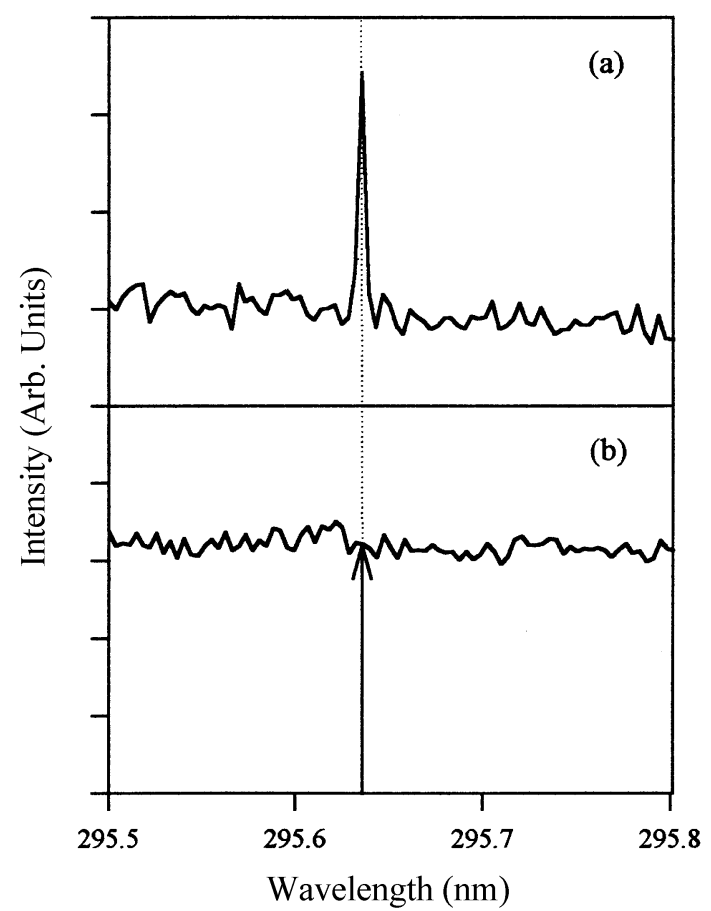

Figure 6. (a) Population change of $\mathrm{Cr}\left(\mathrm{a}^{5} \mathrm{D}_{4}\right)$ atoms by changing the photolysis laser wavelength. The probe laser lrequency was set at $\left.2^{5} \mathrm{~T}^{\circ} \leftarrow \mathrm{a}^{\circ} \mathrm{l}\right)$, transition $(391.9 \mathrm{~nm})$ and the fluorescence from $z^{5} \mathrm{D}_{4}{ }^{\circ} \rightarrow \mathrm{a}^{5} \mathrm{D}_{3}$ transition was monitor at $388.8 \mathrm{~nm}$. The delay tims between photolysis and probe pulses was $2 \mu$ s. (b) Intensities of the CI. signal monitored at $500 \mathrm{~nm} \mathrm{w}$, photolysis laser wavelength. A $10 \% \mathrm{O}_{2}$ in $\mathrm{He}$ mixture was slowly flowed over $\mathrm{Cr}\left(\mathrm{CO}_{6}\right.$ powder at $273 \mathrm{k}$ and the total pressure in the cell was 0.5 Torr.

of the $a^{5} D_{4}$ state population $v$ s. photolysis laser wavelength, which was probed at $2 \mathrm{~ms}$ after the photolysis laser pulse. The probe laser wavelength was $391.9 \mathrm{~nm}\left(7^{5} \mathrm{D}_{4}{ }^{\circ} \leftarrow a^{5} \mathrm{D}_{4}\right)$ and the fluorescence from the $z^{5} \mathrm{D}_{4}{ }^{6} \rightarrow \mathrm{a}^{5} \mathrm{D}$; transition was monitored at $388.8 \mathrm{~nm}$. It is seen that the population of the $\mathrm{a}^{5} \mathrm{D}_{4}$ state can be increased by 3.5 times at $295.64 \mathrm{~mm}$. The CL, intensities shown in Figure $6(\mathrm{~b})$, however, remain effectively the same. Thus, the $\mathrm{a}^{5} \mathrm{D}_{\mathrm{J}}$ state seems not responsible for the $C L$ signal based on this optical pumping experiment.

\section{Discussion}

The first-order dependence of $\mathrm{CL}$ intensities upon $\mathrm{O}_{2}$ pressure and absence of $\mathrm{CL}$ signal from $\mathrm{Cr}(\mathrm{CO})_{6} / \mathrm{N}_{2} \mathrm{O} / \mathrm{He}$ mixtures support that $\mathrm{O}_{2}$ is one of the primary reactants. Also, the second-order dependence of both $\mathrm{CL}$ and $\mathrm{LIF}$ intensities for those $a^{7} S_{3}, a^{5} S_{2}$, and $a^{5} D_{j}$ states of $C r$ atoms on the photolysis laser power supports that the $\mathrm{CL}$ intensities derive from the low-lying states of $\mathrm{Cr}$ atoms. Thus, the chemical species that gives CL signal must be a product from direct reactions of $\mathrm{O}_{2}$ and low-lying states of $\mathrm{Cr}$ atoms. Since photodissociation of gas-phase $\mathrm{Cr}(\mathrm{CO})$, by UV laser is very fast, ${ }^{2.3 .24}$ we ruled out the $\mathrm{Cr}(\mathrm{CO})_{*}^{*}(x=1-6)$ intermediate species generated by two-photon absorption as a plausible reactant for the emitting species in this work.

The CL spectra in rigure 1 is completely different from that of $\mathrm{CrO}^{*}$ produced from the reaction of $\mathrm{Cr}$ atoms with $\mathrm{O}$; reported by Devore and Gole. ${ }^{25}$ The reaction of $\operatorname{Cr}\left(a^{7} \mathrm{~S}_{3}\right)$ with $\mathrm{O}_{3}$ is highly exothermic to generate electronically excited states of $\mathrm{CrO}$, while the reaction of $\mathrm{Cr}\left(\mathrm{a}^{7} \mathrm{~S}_{3}\right)$ with $\mathrm{O}_{2}$ is $0.38 \pm 0.09 \mathrm{eV}$ endothermic to generate ground state CrO. ${ }^{10}$ Since the three low-lying atomic states are generated dominantly by two-photon absorption, the maximum available kinetic energies are about $1.7 \mathrm{eV}$ for the $\operatorname{Cr}\left(\mathrm{a}^{7} \mathrm{~S}\right)$ atoms and about $0.8 \mathrm{eV}$ for the $\operatorname{Cr}\left(\mathrm{a}^{5} \mathrm{~S}_{2}\right)$ and $\operatorname{Cr}\left(\mathrm{a}^{5} \mathrm{D}_{0}\right)$ atoms, considering the energy required for complete dissociation of six carbonyl groups is $6.68 \mathrm{eV}^{26.27}$ The actual kinetic energies of the $\mathrm{Cr}$ atoms should be much smaller than the maximum available kinetic energies since the $\mathrm{CO}$ fragments take away substantial amount $(<0.5 \mathrm{eV})$ of the absorbed energies. ${ }^{27.28}$ Thus, the $\mathrm{Cl}$. species in this work cannot be $\mathrm{CrO}^{*}$, because the available energy is not sufficient to generate $\mathrm{CrO}^{*}$. The absence of $\mathrm{Cl}$. signal from $\mathrm{Cr}(\mathrm{CO})_{6} / \mathrm{N}_{2} \mathrm{O} / \mathrm{He}$ mixtures also supports this argument because the reaction of $\operatorname{Cr}\left(\mathrm{a}^{7} \mathrm{~S}_{3}\right)$ with $\mathrm{N}_{2} \mathrm{O}$ to generate $\mathrm{CrO}$ is highly exothermic.

If the emitting species are direct products from reactions of $\mathrm{Cr}$ atoms with $\mathrm{O}_{2}$, only plausible candidate is $\mathrm{CrO}_{2}{ }^{*}$ generated by the following reactions.

$$
\begin{aligned}
& \mathrm{Cr}^{2}\left(\mathrm{a}^{7} \mathrm{~S}_{3}\right)+\mathrm{O}_{2}-\mathrm{He}(\mathrm{Ar}) \rightarrow \mathrm{CrO}_{2} *+\mathrm{He}(\mathrm{Ar}) \\
& \mathrm{Cr}^{5}\left(\mathrm{a}^{5} \mathrm{~S}_{2}\right)+\mathrm{O}_{2}-\mathrm{He}(\mathrm{Ar}) \rightarrow \mathrm{CrO}_{2} *+\mathrm{He}(\mathrm{Ar}) \\
& \mathrm{Cr}^{2}\left(\mathrm{a}^{5} \mathrm{D}_{\mathrm{I}}\right)+\mathrm{O}_{2}-\mathrm{He}(\mathrm{Ar}) \rightarrow \mathrm{CrO}_{2} *+\mathrm{He}(\mathrm{Ar})
\end{aligned}
$$

However, as shown in Figure 6, 3.5 times increased population of $\mathrm{Cr}\left(\mathrm{a}^{5} \mathrm{D}_{4}\right)$ atoms by optical pumping did not affect the $\mathrm{Cl}$. intensities. We also attempted to increase the population of $\mathrm{Cr}\left(\mathrm{a}^{5} \mathrm{~S}_{2}\right)$ atoms by optical pumping, but the $\mathrm{Cl}$. intensities were not affected. Thus, the optical pumping results suggest that Гqs. (2) and (3) are not the major channel for the formation of $\mathrm{CrO}_{2} *$ in this work, although we cannot rule out Fis. (2) and (3) completely,

Martinez. has studied the reaction of a $\mathrm{Cr}\left(\mathrm{a}^{7} \mathrm{~S}_{3}\right)$ atom with $\mathrm{H}_{2}, \mathrm{~N}_{2}$, and $\mathrm{O}_{2}$ using a density functional theory. $\mathrm{He}$ has reported that the reaction of a $\left.\mathrm{Cr}^{7} \mathrm{a}^{7} \mathrm{~S}_{3}\right)$ atom with ground state $\mathrm{O}_{2}$ is highly exthothermic and the ground state $\mathrm{CrO}_{2}\left(\mathrm{X}^{\mathrm{i}} \mathrm{B}_{2}\right)$ is located at $525.5 \mathrm{~kJ} / \mathrm{mol}$ below the dissociation limit. He has also found that there exist thermodynamically stable $\mathrm{CrO}_{2}$ molecular states locating at 124.3, 134.7. 219.7, $337.2,340.2$, and $466.5 \mathrm{~kJ} / \mathrm{mol}$, respectively, below the dissociation limit. Thus, the $\mathrm{CL}$ emissions observed in this work are energetically in the plausible range among the various $\mathrm{CrO}_{2}$ molecular states generated from the reaction of the ground state $\mathrm{Cr}$ atom with $\mathrm{O}_{2}$.

Parnis and co-workers have studied the reaction (1) in the presence of large amount of Ar buffer gas, but they did not observe chemiluminescence or LIf from ground state $\mathrm{CrO}$ molecules. ${ }^{17}$ They have monitored the disappearance rate of $\operatorname{Cr}\left(\mathrm{a}^{7} \mathrm{~S}_{3}\right)$ atoms at various Ar pressures, and shown that the pseudo-second-order rate constant for removal of the ground state $\mathrm{Cr}\left(\mathrm{a}^{7} \mathrm{~S}_{3}\right)$ atoms by $\mathrm{O}_{2}$ depends on the $\mathrm{Ar}$ buffer gas pressure. They concluded that the $\operatorname{Cr}\left(\mathrm{a}^{7} \mathrm{~S}_{3}\right)$ atoms react readily with $\mathrm{O}_{2}$ to form $\mathrm{CrO}_{2}$ association complex based on their large termolecular rate constant. Although we did not measure the removal rate constants for $\mathrm{Cr}\left(\mathrm{a}^{7} \mathrm{~S}_{3}\right)$ atoms by $\mathrm{O}_{2}$ 
at different buffer gas pressures in this work, the rate constant measured in the presence of 0.45 Torr of $\mathrm{He}$ is in accord with the results of Parnis and co-workers, when their data are extrapolated to lower buffer gas pressures. Nevertheless, Parnis and co-workers did not detect $\mathrm{Cl}$. signal. As shown in Figure $3(\mathrm{~b})$, the $\mathrm{Cl}$, intensities were very sensitive to $\mathrm{Ar}$ pressure. This sensitive dependence of $\mathrm{Cl}$. intensities on Ar pressure manifest itself why Parnis and co-workers did not succeed to observe any $\mathrm{Cl}$. signal under their experimental conditions.

The shapes of $\mathrm{Cl}$. time profiles shown in Figure $3(\mathrm{~b})$, the results of optical pumping, and no detection of $\mathrm{Cl}$, signal by Parnis and co-workers can be qualitatively explained if we assume that hot ground state $\mathrm{Cr}$ atoms generated by twophoton dissociation of $\mathrm{Cr}(\mathrm{CO})_{6}$ at relatively low pressures react with $\mathrm{O}_{2}$ to form $\mathrm{CrO}_{2} *$ which gives $\mathrm{Cl}$, signal in this work. Then, at higher Ar buffer gas pressures, fast collisional cooling of hot $\mathrm{Cr}$ atoms may prevent the formation of $\mathrm{CrO}_{2}{ }^{*}$. At higher partial pressures of $\mathrm{O}_{2}$, increased collision probabilities between the hot ground state $\mathrm{Cr}$ atoms and $\mathrm{O}_{2}$ would decrease the rise time of the CI. signal, however, $\mathrm{O}_{2}$ might also quench $\mathrm{CrO}_{2}$ * quite effectively. Also, the optical pumping of $\mathrm{a}^{5} \mathrm{D}_{4}$ atoms may not affect the $\mathrm{CI}$. intensities if hot ground state $\mathrm{Cr}$ atoms are responsible for the CI. because only a minor portion of the ground state population can be optically pumped using a UV laser with $\sim 10 \mathrm{~ns}$ pulse width.

To confirm these arguments, we have looked for the variation of Doppler line width of the $7^{5} \mathrm{D}_{4} \leftarrow \mathrm{a}^{7} \mathrm{~S}_{\text {3 }}$ absorption spectrum vs, delay time. As plotted in Figure 7, the $7: \mathrm{D}_{4}$

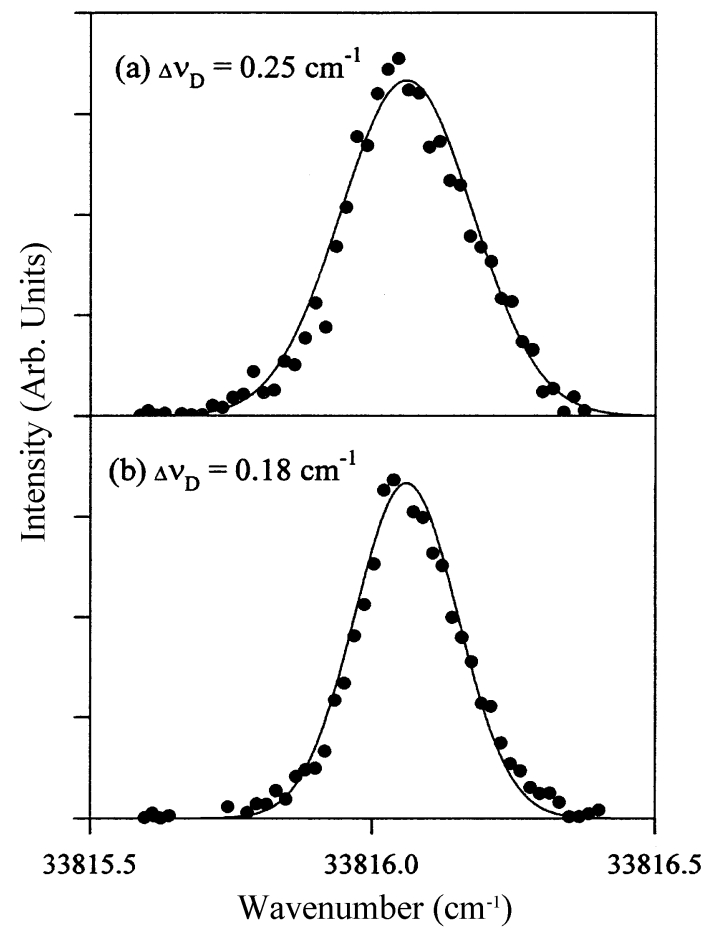

Figure 7. The $z^{5} \mathrm{D}_{4} \leftarrow \mathrm{a}^{7} \mathrm{~S}_{3}$ absorption line profile at different delay time. The delay time hetween the photolysis and probe pulses was (a) $0 \mu \mathrm{s}$ and (b) $5 \mu \mathrm{s}$. The $\mathrm{Ar}$ gas was slowly lowed over $\mathrm{Cr}(\mathrm{CO})$ powder at $273 \mathrm{~K}$ and the eell pressure was 2.0 \%orr. $\leftarrow \mathrm{a}^{7} \mathrm{~S}_{3}$ absorption line width at 2.0 Torr was much broader than the excitation laser line width of $\sim 0.1 \mathrm{~cm}^{-1}$ (FWHM), and decreased substantially at $5 \mu$ s delay time. When the observed Doppler line profiles were deconvoluted for the excitation laser line width $\left(0.1 \mathrm{~cm}^{-1}\right)$, the Gaussian Doppler width (FWHM) with 0.25 and $0.18 \mathrm{~cm}^{-1}$, respectively, were fitted fairly well for the experimental profiles at zero and 5 $\mu$ s delay times, respectively. The Doppler width at zero delay time corresponded to a translational temperature of $6200=500 \mathrm{~K}$, which is in accord with Tyndall and Jackson. ${ }^{22}$ On the other hand, the Doppler width at $5 \mu$ s delay time corresponded to a translational temperature of $2900 \pm 700 \mathrm{~K}$ indicating fast collisional cooling subsequent to the formation of hot $\operatorname{Cr}\left(\mathrm{a}^{7} \mathrm{~S}_{3}\right)$ atoms. Although we did not investigate the Doppler width of the $\operatorname{Cr}\left(a^{5} \mathrm{~S}_{2}\right)$ and $\operatorname{Cr}\left(a^{5} \mathrm{D}_{0}\right)$ atoms generated by two-photon absorption of $\mathrm{Cr}(\mathrm{CO})_{6}$, they should possess much smaller kinetic energies than the $\mathrm{Cr}\left(\mathrm{a}^{7} \mathrm{~S}_{3}\right)$ atoms and formation of $\mathrm{CrO}_{2}^{*}$ might be unfavorable. However, considering the relatively fast disappearance rate constant which corresponds to the sum of physical and chemical guenching of the $\operatorname{Cr}\left(\mathrm{a}^{5} \mathrm{~S}_{2}\right)$ and $\operatorname{Cr}\left(\mathrm{a}^{5} \mathrm{D}_{0}\right)$ atoms, following exothermic reactions seem to be one of the exit channel. ${ }^{2 \text { s }}$

$$
\begin{aligned}
& \mathrm{Cr}^{2}\left(\mathrm{a}^{5} \mathrm{~S}_{2}\right)-\mathrm{O}_{2} \rightarrow \operatorname{CrO}\left(\mathrm{X}^{5} \mathrm{I} \mathrm{l}\right)-\mathrm{O}\left({ }^{3} \mathrm{P}\right) \Delta \mathrm{H}^{0}--50.8 \mathrm{~kJ} / \mathrm{mol} \\
& \mathrm{Cr}^{2}\left(\mathrm{a}^{5} \mathrm{D}_{0}\right)+\mathrm{O}_{2} \rightarrow \operatorname{CrO}\left(\mathrm{X}^{5} \mathrm{l} \mathrm{I}\right)+\mathrm{O}\left({ }^{3} \mathrm{P}\right) \Delta \mathrm{H}^{0}--52.7 \mathrm{~kJ} / \mathrm{mol}
\end{aligned}
$$

The larger disappearance rate constant for the $\mathrm{a}^{5} \mathrm{~S}_{2}$ state $\left(4 \mathrm{~s}^{1} 3 \mathrm{~d}^{5}\right)$ which locates $158-715 \mathrm{~cm}^{-1}$ lower in energy than the $a^{5} D_{1}$ state $\left(4 s^{2} 3 d^{1}\right)$ may reflect that $T M$ atoms having $s^{1} d^{n-1}$ electron configuration are more reactive than those having $\mathrm{s}^{2} \mathrm{~d}^{\mathrm{n}-2}$ electron configuration, ${ }^{5}$

Parson has reported a $\mathrm{Cl}$. spectrum peaked at $\sim 320 \mathrm{~nm}$ from his beam-gas experiment with $\mathrm{Cr}+\mathrm{O}_{2}$, and concluded that the chemical species responsible for the observed $\mathrm{Cl}$. spectrum is $\mathrm{CrO}_{2}{ }^{*}$ generated by a two-body radiative recombination (2BRR) mechanism. ". We have also attempted to look for the $\mathrm{Cl}$ band peaked at $\cdots 320 \mathrm{~nm}$, but the CL. intensities in the 300-350 mm region are very weak under our experimental conditions. Although the spectral range and overall shape of the CL spectrum in Figure I are much different from the Parson's spectrum, the first-order dependence of $\mathrm{CL}$ intensities on $\mathrm{O}_{2}$ pressure and the suppression of $\mathrm{CL}$ intensities by the presence of excess Ar suggest that the $C L$ signal in this work might be another example of $2 B R R$. It is difficult to explain the nature of different $C L$ spectra reported by Parson and in this work, since the excited state potential surfaces of $\mathrm{CrO}_{2}$ molecules are not available yet.

Acknowledgement. ] This work was supported by Korea Research Foundation Grant (KRF-2000-015-DP02I4) and $\mathrm{B} K 2$ ].

\section{References}

1. Campbell. M. L.: Kölsch. E. I.: Hooper. K. L. f. Phys (Then. A 2000. 1114.11$] 47$ 
2. Chertihin. G. V: Bare. W. D.: Andrews. L. J. Ghem. Phns. 1997. 107.2798.

3. Martinez. A. J. Phts Chem .A 1998. 102, 1381.

4. Ritter, D.; Weisshar J. C. J. Phis. Chem 1989.93. 1576.

5. Brown. C. E.: Mitchell. S. A. Hackett. P. A. J. Phvs Chent 1991. 95. 1062

6. Futerko. P. M.: Fontijn. A. J. Chem. Phys. 1991. 95. 8065.

7. Camplell. M. L.: McClean. R. E.: Harter. J. S. S. Chem. phns. Lett. 1995. 235.497.

8. Matsui, R.: Senba. K.: Honna K. Chent. Phns Lett 1996, 250. 560 ).

9. Parson. J. M.: Geiger. L. C.: Conway, T. J. J. Chem. Phts 1981. 74. 5595 .

10. Hedgecock. I. M.: Naulin. C.: Coates. M. Chem. Phns. Lett. 1996. 207.379 .

11. Akhmadov. U. S.: Zaslonko. I. S.: Smimov V. N. Kinet Catal. $1988,29,251$.

12. Helmer, M.: Plane, J. M. C. J. Chent. Soc. Faradav Trans. 1994. 90.31 .

13. Chalek. C. L.: Gole. J. L. Chem. Phs 1977. 19.59

14. Dubois. L. H.: Gole. J. L. J. Chem. Phns. 1977. 66. 779.

15. Jones, R. W: Gole, I. L. J. Chent Phis $1976.65,3800$

16. Ritter D.: Weisshar. J. C. J. Phis Chem. 1990. 94. 4907.

17. Parnis. J. M.: Mitchell. S. A.: Hackett. P. A. J. Phws. Chem. 1990. 94.8152

18. (a) Son. H. S.: Lee. K.: Shin. S. K.: Ku. J. K. Chem. Phns. Lett.
2000. 320. 658. (b) Son1. H. S.: Lee. K.: Kim. S. B.: Ku. J. K. Bull Soman Chem. Soc. 2000. 21.583.

19. Son. H. S.: Ku. J. K. Bull Korean Chem. Soc. 2002. 23, 184.

20. Moore. C. E. Atomic Energy levels as Derived from the Analysis of Optical Spectra. Vol. II, Natl. Stand Ref. Data Set (LIS. Natl. Bur: Stond.) 1971. NSRDS-XBS 35.

21. Martit1. G. A.: Fuhr. T. R.: Wiese. W. L. J. Phus. Chem. Ref. Data 1988. 17. Suppl. 3.

22. Tyndall. G. W.; Jackson, R. L. J. Chem. Phws. 1988, 89. 1364

23. (a) Trushin. S. A.: Fuss. W.: Schmid. W. E.: Kompa, K. L. J. Phos. Chent A 1998. 102. 4129. (b) Gutmann, M.; Janello, J. M: Dickebohm. M. S.: Grossekathoter. M.: Lindener-Roenneke. J. J Phus. Chem \& 1998. 102. 4138.

24. Jachson1. R. L. Acc. Chem Res. 1992. 25.581.

25. Devore. T. C.; Gole, J. L. Chent. Ph.s. 1989. 133. 95.

26. Pilcher. G.; Ware. M. J.; Pittam. D. A. J. Less-Conmon Met. 1975. 42. 223 .

27. Peifer. W. R.: Garvey. J. F. J. Chem. Phus. 1991.94.4821

28. (a) Waller. I. M.: Hepburn. T. W. J. Chem. Phus. 1988. 88.6658 (b) Waller. I. M.: Davis. H. F.: Hepburn. T. W. J. Phys. Chem. 1987. 91,506

29. Chase. M. W.. Jr; Davies. C. A.; Downey, J. R.. Jr; Frurip. D. J.; MoDonald. R. A.; Syverud. A. N. J. Phws. Chem. Ref. Data 1985. 14. Suppl. 1. (IANAF Thermochemical Table)

30. Parson. T. M. J. Phus. Chem. 1986. 90. 1811 